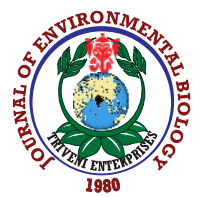

\title{
Dietary shatavari, Asparagous racemosus root extract promotes growth, feed conversion and nutrient utilization in Labeo rajasthanicus
}

\author{
N.R. Keer', N.K. Chadha ${ }^{1 *}$, V.P. Saini', M.L. Ojha ${ }^{3}$ and P.B. Sawant ${ }^{1}$ \\ 'Division of Aquaculture, Central Institute of Fisheries Education, Mumbai-400 061, India \\ ${ }^{2}$ Directorate of Research, Maharana Pratap University of Agriculture and Technology, Udaipur-313001, India \\ ${ }^{3}$ College of Fisheries, Maharana Pratap University of Agriculture and Technology, Udaipur-313001, India \\ *Corresponding Author Email : nkchadha@cife.edu.in
}

\section{Abstract}

Aim: The objective of the study was to assess the effect of supplementation with dietary shatavari, Asparagous racemosus root extract on growth, feed conversion and nutrient utilization in Labeo rajasthanicus.

Methodology: Two-hundred-seventy fingerlings of equal size $(8.19 \pm 0.03 \mathrm{~g})$ were stocked in 18 fibre reinforced plastic tanks following complete randomized design. Six iso-nitrogenous ( $30 \%$ crude protein) and iso-caloric ( $390 \mathrm{kcal}$ digestible energy per $100 \mathrm{~g}$ ) diets were prepared with graded level of ethanolic shatavari root extract, i.e., $0.00,0.15,0.30,0.45,0.60,0.75 \mathrm{~g} \mathrm{~kg}^{-1}$ and designated as control, T1, T2, T3, T4 and T5 were fed to $L$. rajasthanicus twice a day for 45 days. The growth performance, feed conversion and nutrient utilisation were considered as response parameters.

Results: Significantly $(P<0.05)$ higher growth performance (weight gain \%, specific growth rate, net yield and mean daily weight gain percentage) and better feed conversion and nutrient utilization (protein efficiency ratio and lipid efficiency ratio) were observed in $\mathrm{T} 1$ group than in other

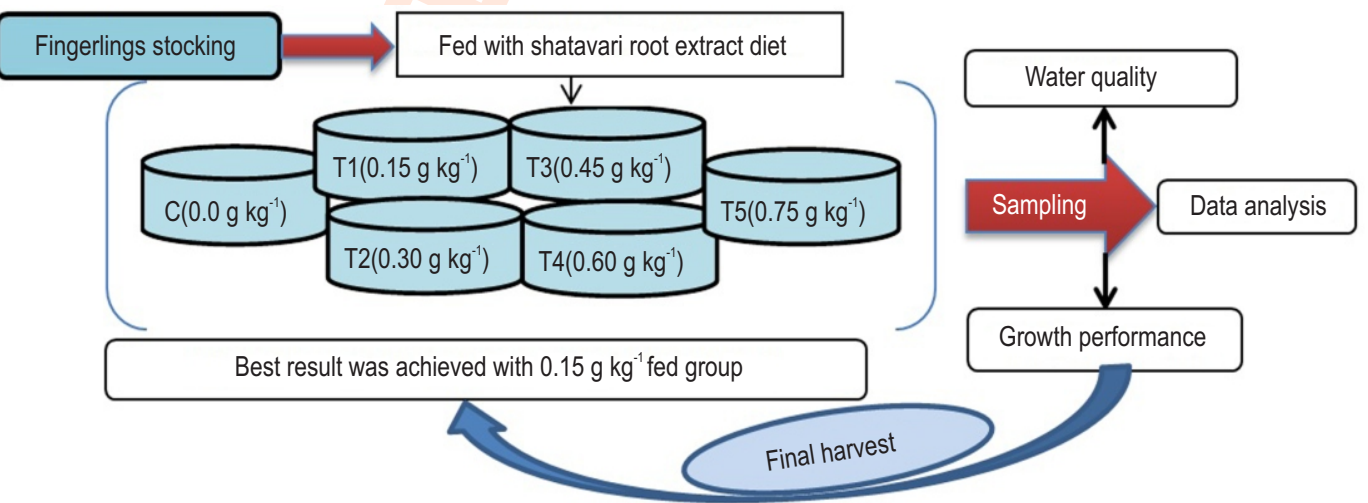
experimental groups.

Interpretation: Based on these findings, it can be concluded that ethanolic extract of shatavari root can be used as a growth promoter and can be included at the supplementation level of $0.15 \mathrm{~g} \mathrm{~kg}^{-1}$ diet for Labeo rajasthanicus.

Key words: Asparagous recemosus, Growth performance, Labeo rajasthanicus, Shatavari root extract

How to cite : Keer, N.R., N.K. Chadha, V.P. Saini, M.L. Ojha and P.B. Sawant: Dietary shatavari, Asparagous racemosus root extract promotes growth, feed conversion and nutrient utilization in Labeo rajasthanicus. J. Environ. Biol., 41, 1464-1469 (2020). 


\section{Introduction}

Different synthetic chemicals are being used as growth promoters and immuno-stimulants for fish and animal feed but cannot be recommended because of their residual accumulation in the body of farm animals (Mägi and Sahk, 2003; Misra et al., 2006, Dawood et al., 2018). Nowadays, different parts (leaf, stem, seed and root) of medicinal plants and their extracts are being used as fish and animal feeds as an alternative to synthetic chemicals to support food production and nutritional security. Use of synthetic chemicals is harmful for aquaculture and these chemicals residuals accumulate in fish body but in case of plant based immunostimulants there will not be anyresiduals accumulation and this will ultimately secure the nutrition of mankind. Medicinal herbs or plants contain different bio-active compounds such as alkaloids, flavonoids, pigments, phenolics, terpenoids, steroids and essential oils, and can be used to enhance growth and immune response in farm animals. Different plants have shown improved growth and immune responses in different finfish and shellfish species such as Penaeusmonodon fed with Cyanodon dactylon, Picrorhiza kurooa, Aegle marmelos, Eclipta alba and Tinospor acordifoli (Citarasu et al., 2006), Tilapia niloticus fed with Foeniculum vulgare (Abd El-Hakim et al., 2010), Fenneropenaeus indicus fed with extracts of Adhatodavasika, Psoralea corylifolia, Ocimum basilicum, Quercus infectoria and Murraya koenigii (Velmurugan and Citarasu, 2010). Similarly, recent studies have shown improved growth in Channa punctatus, fed with Asparagus racemosus and Withania somnifera (Borkar et al., 2014), Macrobrachium rosenbergi fed with Alteranthera sessilis, Eclipta alba and Cissus quadrangularis (Radhakrishnan et al., 2014), Cyprinus carpio fed with Ocimum basilicum (Amirkhani and Firouzbakhsh, 2015), Macrobrachium malcomsoni fed with Alteranthera sessilis, Eclipta alba and Cissus quadrangularis (Radhakrishnan et al., 2015), Labeo rohita fed with extract of Mucuna pruriens (Ojha et al., 2014) and Houttuynia cordata (Garg et al., 2019), as well as to improve immunity and to cure various diseases (Citarasu et al., 2006; Sivaram etal., 2004).

Shatavari, Asparagus racemosus belongs to family Asparagaceae and is a climbing plant, which grows in low forest areas throughout tropical and subtropical counties (Sharma and Sharma, 2013). Various bio-active compounds are found in shatavari leaf and root such as polyphenols, polysaccharides, steroidal saponins, flavonoids and oligosaccharides (Chawla et al., 2011; Fuentes-Alventosa et al., 2013), which promote the growth of the animals through cellular metabolic activities. It has been reported that the shatavari plant has medicinal values and improves immune status in mammals (Thakur et al., 2009; Kumar et al., 2010; Alok et al., 2013) and has been identified as a growth promoter in snakehead fish (Borkar et al., 2014), however, information on the role of Asparagous racemosus root extract added as a feed supplement in carp feed is meagre.

Labeo rajasthanicus, commonly known as Sarsi is an indigenous minor carp of India found in the water bodies of
Rajasthan, India. The natural habitat of $L$. rajasthanicus includes water bodies with rocky substrates for shelter with a depth up to 20 m along with low water current, Sarsi is a candidate species for carp polyculture (Lal et al., 2015). L. rajasthanicus has good market value as an important food and the captive brood stock already has been raised and produced seeds that can be used for aquaculture and enhancement (Anon, 2014). With this background, the aim of the present study was to assess the effect of dietary shatavari root extract on the growth performance, feed conversion and nutrients utilization in the fingerlings of $L$. rajasthanicus.

\section{Materials and Methods}

Preparation of herbal extract: The roots of shatavari was procured from Udaipur, Rajasthan and authentication was done at the Botany Department of College of Science, Mohanlal Sukhadia University, Udaipur, India. The collected roots were washed with tap water and further in distilled water for complete removal of dust particles and dried under shade, followed by grinding to fine powder. The fine root powder was transferred to a $250 \mathrm{ml}$ glass beaker containing $100 \mathrm{ml} 80 \%$ ethanol (v/v) and shaken in an orbital shaker (Orbitek $B$ - Scigenics Biotech, Chennai, India) at $160 \mathrm{rpm}$ for $24 \mathrm{hr}$, followed by filtering the solution using a muslin cloth. Filtrates were centrifuged at 10,000 rpm at $4^{\circ} \mathrm{C}$ for $5 \mathrm{~min}$ and the supernatant was collected. A rotatory evaporator (IKA® RV10 Basic-Shanghai, China; temperature of $40-60^{\circ} \mathrm{C}$, rotor speed of $40 \mathrm{rpm}$ ) was used to concentrate the supernatant. The concentrate was transferred to screw-cap bottle and stored at $4^{\circ} \mathrm{C}$ for $24 \mathrm{hr}$ and freeze-dried $\left(-95^{\circ} \mathrm{C} \pm 4^{\circ} \mathrm{C}\right)$, followed by storage in a deep freezer $\left(-20^{\circ} \mathrm{C}\right)$ until further use. The yield percentage of crude extract was around $15.45 \%$ by weight of shatavari root powder.

Preparation of diet: According to the feed formulation (Table 1), all the ingredients were weighed and thoroughly mixed in a container to form a homogenous blend, and dough was formed. The dough was autoclaved for $20 \mathrm{~min}$ to ensure proper gelatinization of starch and allowed to cool. Fish oil and sunflower oil, vitamin-mineral mixture, butylated hydroxytoluene and Vitamin $\mathrm{C}$ were added along with the shatavari root extract, and mixed properly. The dough was pressed through a pelletizer (S.B. Panchal and Company, Mumbai, India) with $2 \mathrm{~mm}$ diameter die to form uniform-size pellets. The pellets were dried in oven at $45^{\circ} \mathrm{C}$ for $12 \mathrm{hr}$ and packed into an air airtight container, followed by storage in dry and cool place for further use.

Proximate composition of diets: The proximate composition of the diets was analysed by using standard protocols (AOAC, 2005). The formulation and proximate composition of the diets are given in Table 1. Moisture content was determined by drying the samples at $105^{\circ} \mathrm{C}$ in a hot air oven till achieving constant weight. The crude protein content of the diets was determined using the micro-Kjeldahl apparatus (Kelplus, PELICAN, Maharashtra, India), and the crude lipid content was estimated by using a Soxhlet ether extractor (SOCS plus, SAS-AS 08 PELICAN, Maharashtra, India). Crude fibre content was 
estimated by using fibre tech (Tuline quipments, Chennai, India) and total ash content was measured using a muffle furnace at 550 ${ }^{\circ} \mathrm{C}$ for $5 \mathrm{hr}$. The nitrogen-free extract was calculated by the subtraction method.

Experimental setup and fish maintenance: An experiment was conducted for a period of 45 days at the Aquaculture Research Unit, Maharana Pratap University of Agriculture and Technology, Udaipur, Rajasthan, India. The fingerlings of $L$. rajasthanicus were obtained from the Aquaculture Research Unit, Maharana Pratap University of Agriculture and Technology, Udaipur, Rajasthan, India. Six iso-nitrogenous (30\% crude protein) and iso-caloric(390 kcal DE/ $100 \mathrm{~g})$ diets were prepared with the inclusion of graded levels of crude ethanolic shatavari root extract, viz. $0.00(\mathrm{C}), 0.15(\mathrm{~T} 1), 0.30(\mathrm{~T} 2), 0.45(\mathrm{~T} 3), 0.60$ (T4) and $0.75(\mathrm{~T} 5) \mathrm{g} \mathrm{kg}^{-1}$.

The experiment was conducted in eighteen fibre reinforced plastic tanks $(1 \times 1 \times 0.75 \mathrm{~m})$. Before assigning to the experimental unit, fish were acclimatised for a period of 15 days and fed with the control diet $(30 \%$ crude protein and $6 \%$ ether extract). Two-hundred and seventy fingerlings (average weight $8.19 \pm 0.03 \mathrm{~g}$ ) were randomly distributed into six different experimental groups in triplicate following a completely randomized design. Continuous aeration was provided to each tank during the entire experimental trial. Experimental fish were fed twice a day (10:00 and 17:00 hr) up to satiation. Uneaten feed and faecal matter were siphoned from the tanks daily, and an equal amount of water was added to maintain a constant water level (500 I).

Water quality analysis: The water quality parameters viz. temperature, dissolved oxygen (DO), pH, alkalinity, ammonia-N, nitrate- $\mathrm{N}$ and nitrite- $\mathrm{N}$ were determined by using standard methods of APHA(2017).

Growth performance, feed conversion, nutrient utilisation and survival: The growth performance (weight gain percentage, specific growth rate, net yield mean daily weight gain percentage and survival), feed conversion and nutrient utilization indices (protein efficiency ratio and lipid efficiency ratio) were determined by using standard methods (Halver and Hardy, 2002).

Table 1: Ingredient proportion and proximate composition of experimental diets supplemented with graded level of shatavari root extract (SRE) during experimental period

\begin{tabular}{|c|c|c|c|c|c|c|}
\hline \multicolumn{7}{|c|}{ Inclusion level of ingredients $\left(\mathrm{g} \mathrm{kg}^{-1}\right)$} \\
\hline Ingredients & C & T1 & T2 & T3 & $\mathrm{T} 4$ & T5 \\
\hline Fish meal $^{1}$ & 100.00 & 100.00 & 100.00 & 100.00 & 100.00 & 100.00 \\
\hline soybean meal ${ }^{1}$ & 200.00 & 200.00 & 200.00 & 200.00 & 200.00 & 200.00 \\
\hline $\mathrm{GNOC}^{1}$ & 200.00 & 200.00 & 200.00 & 200.00 & 200.00 & 200.00 \\
\hline $\mathrm{DORB}^{1}$ & 320.00 & 320.00 & 320.00 & 320.00 & 320.00 & 320.00 \\
\hline Wheat flour $^{1}$ & 118.70 & 118.55 & 118.40 & 118.25 & 118.10 & 117.95 \\
\hline Cod liver oil ${ }^{2}$ & 20.00 & 20.00 & 20.00 & 20.00 & 20.00 & 20.00 \\
\hline Sunflower oil ${ }^{2}$ & 20.00 & 20.00 & 20.00 & 20.00 & 20.00 & 20.00 \\
\hline Vitamin-mineral mix $^{3}$ & 20.00 & 20.00 & 20.00 & 20.00 & 20.00 & 20.00 \\
\hline BHT4 & 0.20 & 0.20 & 0.20 & 0.20 & 0.20 & 0.20 \\
\hline Choline chloride $^{4}$ & 1.00 & 1.00 & 1.00 & 1.00 & 1.00 & 1.00 \\
\hline Vitamin $C^{4}$ & 0.10 & 0.10 & 0.10 & 0.10 & 0.10 & 0.10 \\
\hline SRE & 0.00 & 0.15 & 0.30 & 0.45 & 0.60 & 0.75 \\
\hline TOTAL & 1000.00 & 1000.00 & 1000.00 & 1000.00 & 1000.00 & 1000.00 \\
\hline \multicolumn{7}{|c|}{ Proximate composition (\% dry weight basis) } \\
\hline Dry matter & $89.05 \pm 0.02$ & $89.06 \pm 0.05$ & $89.17 \pm 0.09$ & $89.17 \pm 0.12$ & $89.10 \pm 0.06$ & $89.07 \pm 0.05$ \\
\hline Crude protein $(\mathrm{CP})$ & $30.75 \pm 0.15$ & $30.07 \pm 0.11$ & $30.79 \pm 0.13$ & $30.82 \pm 0.20$ & $30.50 \pm 0.08$ & $30.41 \pm 0.11$ \\
\hline Ether extract (EE) & $5.88 \pm 0.07$ & $5.92 \pm 0.04$ & $5.91 \pm 0.05$ & $6.01 \pm 0.03$ & $5.94 \pm 0.04$ & $5.90 \pm 0.05$ \\
\hline Crude fibre (CF) & $5.14 \pm 0.04$ & $5.09 \pm 0.05$ & $5.10 \pm 0.07$ & $5.09 \pm 0.05$ & $5.12 \pm 0.05$ & $5.12 \pm 0.05$ \\
\hline Nitrogen-free extract (NFE) $)^{5}$ & $53.11 \pm 0.27$ & $53.31 \pm 0.10$ & $53.06 \pm 0.23$ & $53.01 \pm 0.19$ & $53.29 \pm 0.11$ & $53.50 \pm 0.09$ \\
\hline Total ash (TA) & $5.12 \pm 0.05$ & $5.13 \pm 0.02$ & $5.14 \pm 0.04$ & $5.07 \pm 0.03$ & $5.15 \pm 0.06$ & $5.07 \pm 0.03$ \\
\hline $\mathrm{De}^{6}\left(\mathrm{kcal} 100 \mathrm{~g}^{-1}\right)$ & $388.00 \pm 0.42$ & $388.74 \pm 0.36$ & $388.62 \pm 0.42$ & $389.43 \pm 0.12$ & $388.63 \pm 0.57$ & $388.72 \pm 0.57$ \\
\hline
\end{tabular}

'Procured from local market, Andheri, Mumbai, India. ${ }^{2}$ Universal Medicare Pvt Ltd, Maharashtra, India. ${ }^{3}$ Virbac Animal Health India Pvt. Ltd., Mumbai [Agrimin- Nutritional value per kg.-Vit. A-7,00,000I.U., Vit.D3-70,000I.U., Vit.E-250 mg, Nicotinamide-1000 mg, Cobalt- 150 mg, Copper-1200 mg, lodine- 325 mg, Iron - 1500 mg, Magnesium- 6000 mg, Maganese- 1500 mg, Potassium-100 mg, Selenium-10 mg, Sodium- 5.9 mg, Sulphur-0.72\%, Zinc$9600 \mathrm{mg}$, Calcium-25.5\% and Phosphorus-12.75\%. ${ }^{4}$ Himedia Laboratories, Mumbai, India. $\left.{ }^{5} \mathrm{NFE}=100-(\% \mathrm{CP}+\% \mathrm{EE}+\% \mathrm{CF}+\% \mathrm{TA})\right] .{ }^{6} \mathrm{Calculated}$

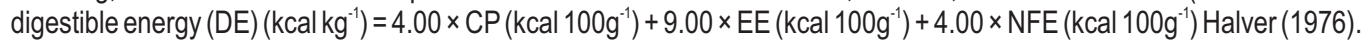


Statistical analyses: The data were analysed by One-way analysis of variance (ANOVA) at $5 \%$ level of significance $(p<0.05)$ between the treatments, and Duncan's Multiple Range Test (DMRT) was applied for post-hoc comparisons using SPSS (Version 16.0, SPSS, USA). The data were expressed as mean \pm S.E.

\section{Results and Discussion}

The perusal of data revealed no significant $(P>0.05)$ differences in temperature, dissolved oxygen, $\mathrm{pH}$, alkalinity, ammonia- $\mathrm{N}$, nitrate- $\mathrm{N}$ and nitrite- $\mathrm{N}$ between the experimental groups. Throughout the experiment, all the parameters were found congenial for fish growth, this resultconfirms earlier findingson desirable water quality parametrs for fish growth (Kumar et al., 2010; Mohapatra et al., 2012;Garg et al., 2019) possibly due to the periodic exchange of water. Valuable animal protein and essential nutrients can be obtained from cultured species of aquaculture, the aquaculture sector increased during the last three decades to meet the required nutrition for world population and human needs. Aquaculture products and by products provide at least twenty percent of protein intake in developing countries and more than fifty percent in the poor countries of Africa and South Asia (Awad and Awaad, 2017). The presence of phytochemical compounds such as steroids, phenolics and alkaloids allure to use of medicinal plants as appetite stimulators and growth promoters in cultured species in aquaculture sector (Awad and Awaad, 2017). In the present study, the growth rates of $L$. rajasthanicus fingerlings in terms of weight gain \%, specific growth rate, mean daily weight gain \% and net yield throughout 45 days were significantly affected
$(P<0.05)$ by different concentrations of dietary shatavari root extract (Table 2).

Significantly $(P<0.05)$ higher weight gain \% was observed in $L$. rajasthanicus fed with $0.15 \mathrm{~g} \mathrm{~kg}^{-1}$ (T1) shatavari root extract followed by $0.30 \mathrm{~g} \mathrm{~kg}^{-1}$ (T2) and $0.45 \mathrm{~g} \mathrm{~kg}^{-1}$ (T3) and lowest in control, $0.75 \mathrm{~g} \mathrm{~kg}^{-1}$ (T5) and $0.60 \mathrm{~g} \mathrm{~kg}^{-1}$ (T4) dietery groups of shatavari root extract. The weight gain $\%$ in fingerlings of $\mathrm{T} 4$ group did not show significant difference $(P>0.05)$ with $\mathrm{T} 3, \mathrm{~T} 5$ and control groups. The specific growth rate in fingerlings was significantly $(P<0.05)$ higher in $T 1$ group, followed by $T 2$ and $T 3$ and lowest in control, $\mathrm{T} 5$ and $\mathrm{T} 4$ dietery groups of shatavari root extract, while T4 group did not show significant difference with T3, T5 and control groups. Similar trend was also noticed in mean daily weight gain $\%$ and net yield. The results of the present study have shown that dietary shatavari root extract at lower dose promoted the growth of $L$. rajasthanicus. The improvement in growth performance might be due to the capability of its bioactive compounds in shatavari root extract which stimulate the secretion of digestive enzymes and enhance absorption of nutrients by improving gut microbiota, this assumption is corroborates the study of Adel et al. (2020), who reported dietary Polygonum minus extract improves growth performance of fish. Similarly, Serra et al. (2018) reported that the presence of bioactive compounds in feed stimulate the secretion of digestive enzyme's, which enhances the absorption of nutrients.

Reduction in growth of fingerlings with the increase of shatavari root extract could be due to increased level of anti nutritional factors (ANFs). The presence of anti nutritional factors

Table 2: Growth performance of groups of Labeo rajasthanicus fingerlings supplemented with graded level of ethanolic shatavari root extract

\begin{tabular}{|c|c|c|c|c|c|c|c|}
\hline Parameters & $C$ & T1 & $\mathrm{T} 2$ & $\mathrm{~T} 3$ & T4 & T5 & $P$ value \\
\hline Initial weight(g) & $8.22 \pm 0.12$ & $8.15 \pm 0.03$ & $8.17 \pm 0.11$ & $8.20 \pm 0.03$ & $8.16 \pm 0.09$ & $8.26 \pm 0.08$ & 0.934 \\
\hline Final weight (g) & $11.96 \pm 0.16^{\mathrm{a}}$ & $13.55 \pm 0.16^{c}$ & $12.76 \pm 0.12^{b}$ & $12.36 \pm 0.08^{\mathrm{ac}}$ & $11.99 \pm 0.14^{\mathrm{a}}$ & $11.94 \pm 0.18^{\mathrm{a}}$ & 0.001 \\
\hline Weight gain (\%) & $45.52 \pm 1.46^{a}$ & $66.23 \pm 1.93^{\mathrm{d}}$ & $56.25 \pm 1.58^{c}$ & $50.81 \pm 1.45^{\mathrm{b}}$ & $46.94 \pm 1.19^{\mathrm{ab}}$ & $44.58 \pm 0.80^{\mathrm{a}}$ & 0.001 \\
\hline $\mathrm{SGR}^{1}$ (\% per day) & $0.36 \pm 0.12^{\mathrm{a}}$ & $0.49 \pm 0.01^{\mathrm{d}}$ & $0.43 \pm 0.01^{c}$ & $0.40 \pm 0.01^{b}$ & $0.37 \pm 0.01^{\mathrm{ab}}$ & $0.36 \pm 0.01^{a}$ & 0.001 \\
\hline $\operatorname{MDWG}^{2}(\%)$ & $8.31 \pm 0.24^{a}$ & $12.00 \pm 0.34^{d}$ & $10.21 \pm 0.22^{c}$ & $9.25 \pm 0.23^{b}$ & $8.51 \pm 0.21^{a b}$ & $8.19 \pm 0.22^{\mathrm{a}}$ & 0.001 \\
\hline Net yield $(\mathrm{g})$ & $56.08 \pm 1.62^{\mathrm{a}}$ & $81.00 \pm 2.33^{\mathrm{d}}$ & $68.90 \pm 1.47^{\circ}$ & $62.45 \pm 1.56^{b}$ & $57.45 \pm 1.44^{\mathrm{ab}}$ & $55.25 \pm 1.49^{\mathrm{a}}$ & 0.001 \\
\hline Survival (\%) & 100 & 100 & 100 & 100 & 100 & 100 & - \\
\hline
\end{tabular}

Values are expressed as mean \pm SEM $(n=3)$. Mean values in the same row not sharing same superscript are significantly different $(P<0.05)$. Note. ${ }^{1}$ SGR: Specific growth rate; ${ }^{2}$ MDWG: Mean daily weight gain

Table 3: Feed utilisation parameters for Labeo rajasthanicus fingerlings fed with graded levels of ethanolic shatavari root extract

\begin{tabular}{|c|c|c|c|c|c|c|c|}
\hline Parameters & $C$ & $\mathrm{~T} 1$ & $\mathrm{~T} 2$ & T3 & $\mathrm{T} 4$ & T5 & $P$ value \\
\hline $\mathrm{FCR}^{1}$ & $3 . .65 \pm 0.10^{d}$ & $2.72 \pm 0.06^{a}$ & $3.08 \pm 0.07^{b}$ & $3.34 \pm 0.08^{c}$ & $3.56 \pm 0.07^{\mathrm{cd}}$ & $3.70 \pm 0.05^{d}$ & 0.001 \\
\hline $\mathrm{PER}^{2}$ & $0.89 \pm 0.02^{\mathrm{a}}$ & $1.21 \pm 0.02^{d}$ & $1.05 \pm 0.02^{c}$ & $0.97 \pm 0.02^{b}$ & $0.92 \pm 0.02^{\mathrm{ab}}$ & $0.89 \pm 0.01^{\mathrm{a}}$ & 0.001 \\
\hline LER $^{3}$ & $4.67 \pm 0.08^{\mathrm{a}}$ & $6.22 \pm 0.10^{d}$ & $5.50 \pm 0.08^{c}$ & $4.99 \pm 0.09^{b}$ & $4.74 \pm 0.09^{\mathrm{ab}}$ & $4.58 \pm 0.10^{\mathrm{a}}$ & 0.001 \\
\hline
\end{tabular}

Values are expressed as mean \pm SEM $(n=3)$. Mean values in the same row not sharing same superscript are significantly different $(P<0.05)$. ${ }^{1}$ FCR: Feed conversion ratio; ${ }^{2}$ PER: Protein efficiency ratio; ${ }^{3}$ LER: Lipid efficiency ratio 
(ANFs) in diet of fish beyond the tolerance limit could decrease the growth rates in fish (Francis et al., 2001; Garg et al., 2019). This is the first report on shatavari root extract fed to $L$. rajasthanicus as a growth promoter. Improved growth performance has been reported in Labeo rohita fed with herbal extract of Houttuynia cordata leaf (Garg et al., 2019), Nile tilapia fed with Panax ginseng root, Ginsana G115 (Goda, 2008) and Cyprinus carpio fed with Epilobium hirsutum (Pakravan et al., 2012). Similarly, various parts of herbal plant or its by-products have been used for years as functional foods, due to their advantageous effects of existing active ingredients on fish, such as growth promotion and immune-stimulation (Immanuel et al., 2009; Abd El - Hakim et al., 2010; Velmurugan and Citarasu, 2010; Borkar et al., 2014; Ojha et al., 2014). Furthermore, recent studies have been shown that herbal preparation in fish feed improves growth and feed utilisation (Musthafa et al., 2018; Garg et al., 2019; Kaleo et al., 2019; Li et al 2019; Yousefi et al., 2019).At the end of experimental trial, dietary shatavari root extract at graded levels did not exhibit any significant $(P>0.05)$ difference on survival of $L$. rajasthanicus fingerlings (Table 2 ).

Feed conversion ratio (FCR) is a comparison quantity of feed used per unit weight gain of fish, offering a measure of aquaculture production efficiency. It also indicates aquatic environmental performance, since it indicates undesirable outputs and nutrients lost to the aquatic environment (Waite et al., 2014). Protein efficiency is a ratio between unit weight gain and unit protein consumed at a specific time. Feed conversion (FCR) and nutrient utilization (protein efficiency ratio and lipid efficiency ration) indices are shown in Table 3; they varied significantly among different dietary treatment groups $(P<0.05)$. Best feed conversion and nutrient utilization were observed in $\mathrm{T} 1$ fed group followed by T2 and T3 groups, while these indices did not vary among control and T4 and T5 fed groups $(P>0.05)$. Higher feed conversion ratio and lower nutients utilisation (PER and LER) in fingerlings of $L$. rajasthanicus fed with higher dose of shatavari root extract could be due to reduction in nutrient absorption by existing anti nutrional factors (ANTs) in root extract.

The present study is in accordance with Francis et al. (2001) where they stated that nutrient absorption decreases with increase in anti nutritional factors (ANTs). The results indicate that feed was well utilized in T1 than all other experimental groups, and the nutrients utilization was also improved with addition of dietary shatavari root extract in T1 group than other groups. Improved feed conversion and nutrient utilization indices (protein efficiency ratio and lipid efficiency ration) in dietary shatavari root extract fed groups might be attributed to the presence of bio-active compounds in shatavari root extract, which improves digestion and absorption of nutrients by increasing the activity of digestive enzymes and gut microbial performance (Radhakrishnan et al., 2015; Dawood et al., 2018; Diana et al., 2018; Garg et al., 2019).

The results of this study corroborates with the reports of previous studies on Labeo rohita fed with herbal extract of Houttuynia cordata leaf (Garg et al., 2019), Cyprinus carpio fed with Ocimum basilicum (Amirkhani and Firouzbakhsh, 2015), Labeo rohita fed with Mucuna pruriens herbal extract (Ojha et al., 2014) and Cyprinus carpio fed with Trifolium pratense (Turan et al., 2007), respectively. From the present study, it can be concluded that ethanolic shatavari root extract improves the growth performance, feed conversion and nutrients utilisation of $L$. rajasthanicus fingerlings. Moreover, best growth rates, feed conversion and nutrients utilisation indices can be obtained in $L$. rajasthanicus fingerlings with $0.15 \mathrm{~g} \mathrm{~kg}^{-1}$ shatavari root extract without any adverse effect on fish health. Further, ethanolic extracts of shatavari root extract at lower doses can be used as a growth promoter for $L$. rajasthanicus fingerlings.

\section{Acknowledgments}

The authors gratefully acknowledge the Director/Vice-Chancellor of ICAR-Central Institute of Fisheries Education, Mumbai and Directorate of Research, MPUAT, Udaipur, Rajasthan, India for providing necessary facilities for conducting this research work.

\section{References}

Abd El Hakim, N.F., M.H. Ahmad, E.S. Azab, M.S. Lashien and E.S. Baghdady: Response of Nile tilapia, Oreochromis niloticus to diets supplemented with different levels of fennel seeds meal (Foeniculum vulgare). Abbassa Int. J. Aqua., 3, 215-230 (2010).

Adel, M., M.A. Dawood, S. Shafiei, F. Sakhaie and S.P.H. Shekarabi: Dietary Polygonum minus extract ameliorated the growth performance, humoral immune parameters, immune-related gene expression and resistance against Yersinia ruckeri in rainbow trout (Oncorhynchus mykiss). Aquaculture, 519, 734738 (2020).

Alok, S., S.K. Jain, A. Verma, M. Kumar, A. Mahor and M. Sabharwal: Plant profile, phytochemistry and pharmacology of Asparagus racemosus (Shatavari): A review. Asian Pac. J. Tro. Dis., 3, 242251 (2013).

Amirkhani, N. and F. Firouzbakhsh: Protective effects of basil (Ocimum basilicum) ethanolic extract supplementation diets against experimental Aeromonas hydrophila infection in common carp (Cyprinus carpio). Aquacult. Res., 46, 716-724 (2015).

Anonymous: Harmonising biodiversity conservation and agricultural intensification through integration of plant, animal and fish genetic resources for livelihood security in fragile ecosystems. Final project report submitted to NAIP-GEF (2014).https:// naip. icar. gov. in/download/gef-biodiversity.pdf.

AOAC: Official Method of Analysis. $18^{\text {th }}$ Edn., Association of Officiating Analytical Chemists, Washington D.C., Method 935.14 and 992.24 (2005).

APHA: Standard Methods for the Examination of Water and Wastewater. $21^{\text {st }}$ Edition, American Public Health Association/American Water Works Association/Water Environment Federation, Washington, DC (2017).

Awad, E. and A. Awaad: Role of medicinal plants on growth performance and immune status in fish. Fish Shellfish Immunol., 67, 40-54 (2017).

Borkar, S.B., S.H. Rathod, K.M. Kulkarni and V.T. Tantarpale: Impact of shatavari and ashwagandha on average body weight of freshwater fish Channa punctatus. J. Global Biosci., 3, 582-585 (2014).

Chawla, A., P. Chawla, R.R. Mangalesh and R. Roy: Asparagus racemosus (Willd): Biological activities and its active principles. Indo. Global J. Pharm. Sci., 1, 113-120 (2011). 
Citarasu, T., V. Sivaram, G. Immanuel, N. Rout and V. Murugan: Influence of selected Indian immuno stimulant herbs against white spot syndrome virus (WSSV) infection in black tiger shrimp, Penaeus monodon with reference to haematological, biochemical and immunological changes. Fish Shellfish Immunol., 21, 372-384 (2006).

Dawood, M.A., S. Koshio and M.Á. Esteban: Beneficial roles of feed additives as immuno stimulants in aquaculture: A review. Rev. Aquacult., 10, 950-974 (2018).

Francis, G., H.P. Makkar and K. Becker: Anti nutritional factors present in plant-derived alternate fish feed ingredients and their effects in fish. Aquaculture, 199, 197-227 (2001).

Fuentes-Alventosa, J.M., S. Jaramillo-Carmona, G. RodríguezGutiérrez, R. Guillén-Bejarano, A. Jiménez-Araujo, J. FernándezBolaños and R. Rodríguez-Arcos: Preparation of bioactive extracts from asparagus by-product. Food Bioprod. Process., 91, 74-82 (2013).

Garg, C.K., N.P. Sahu, N. Shamna, A.D. Deo, F.J. Fawole, S. Kumar and M.K. Maiti: Effect of dietary Houttuynia cordata leaf meal and leaf extract on the growth performance, nutrient utilization and expression of IGF-I gene in Labeo rohita. Aquacult. Nutr., 25, 702$711(2019)$

Goda, A.M.S.: Effect of dietary Ginseng herb (Ginsana® G115) supplementation on growth, feed utilization and hematological indices of Nile Tilapia, Oreochromis niloticus (L.), fingerlings. J. World Aquacult. Soc., 39, 205-214 (2008).

Halver, J.E.: Formulating practical diet for fish. J. Fish. Bd. Can., 33, 1032-1039 (1976).

Halver, J. E. and R.W. Hardy: Fish nutrition. In: Ingredient and Diet Evaluation: Biological Evaluation. $3^{\text {rd }}$ Edn., Elsevier, pp. 588 (2002).

Immanuel, G., R.P. Uma, P. Iyapparaj, T. Citarasu, S.M.P. Peter, M.M. Babu and A. Palavesam: Dietary medicinal plant extracts improve growth, immune activity and survival of tilapia Oreochromis mossambicus. J. Fish Biol., 74, 1462-1475 (2009).

Kaleo, I.V., Q. Gao, B. Liu, C. Sun, Q. Zhou, H. Zhang, F. Shan, Z. Xiong, L. Bo and C. Song: Effects of Moringa oleifera leaf extract on growth performance, physiological and immune response and related immune gene expression of Macrobrachium rosenbergii with Vibrio anguillarum and ammonia stress. Fish Shellfish Immunol., 89, 603-613 (2019).

Kumar, M.V., S. Saima, A. Vineet and C. Nitin: Effects of Asparagus racemosus (Shatavari), on mounting behaviour of male rats. Int. J. Pharm. Life Sci., 1, 30-34 (2010).

Kumar, V., N.P. Sahu, A.K. Pal, S. Kumar, A.K. Sinha, J. Ranjan and K. Baruah: Modulation of key enzymes of glycolysis, gluconeogenesis, amino acid catabolism and TCA cycle of the tropical freshwater fish Labeo rohita fed gelatinized and non-gelatinized starch diet. Fish Physiol. Biochem., 36, 491-499 (2010).

Lal, K.K., B.K. Gupta, P. Punia, V. Mohindra, V.P. Saini, A.K. Dwivedi, R.K. Singh, S. Dhawan, R.K. Luhariya, V.S. Basheer and J.K. Jena: Revision of gonius sub group of the genus Labeo Cuvier, 1816 and confirmation of species status of Labeo rajasthanicus (Cypriniformes: Cyprinidae) with designation of a neotype. Indian J. Fish., 62, 10-22 (2015).

Li, H., D. Yang, Z. Li, M. He, F. Li, J. Jiang, S. Tang, P. Peng, W. Du, Y. Ma and Y. Liu: Effects of Angelica sinensis extracts on lipid oxidation in fish feeds and growth performance of juvenile Jian carp (Cyprinus carpio var. Jian). Anim. Nutr., 5, 109-114 (2019).

Mägi, E. and M. Sahk: Use of herbal medicine principles in local conditions. Agraarteadus, 14, 172-178 (2003).
Misra, C.K., B.K. Das, S.C. Mukherjee and P. Pattnaik: Effect of multiple injections of $\beta$-glucan on non-specific immune response and disease resistance in Labeo rohita fingerlings. Fish Shellfish Immunol., 20, 305-319 (2006)

Mohapatra, S., T. Chakraborty, A.K. Prusty, P. Das, K. Paniprasad and K.N. Mohanta: Use of different microbial probiotics in the diet of rohu, Labeo rohita fingerlings: Effects on growth, nutrient digestibility and retention, digestive enzyme activities and intestinal microflora. Aquacult. Nutr., 18, 1-11 (2012).

Musthafa, M.S., S.M. Asgari, A. Kurian, P. Elumalai, A.R.J. Ali, B.A. Paray and M.K. Al-Sadoon: Protective efficacy of Mucuna pruriens (L.) seed meal enriched diet on growth performance, innate immunity and disease resistance in Oreochromi smossambicus against Aeromonas hydrophila. Fish Shellfish Immunol., 75, 374-380 (2018).

Ojha, M.L., N.K. Chadha, V.P. Saini, S. Damroy, S.P. Chandraprakash and P.B. Sawant: Effect of ethanolic extract of Mucuna pruriens on growth, metabolism and immunity of Labeo rohita (Hamilton, 1822) fingerlings. Int. J. Fauna Biol. Stud., 1, 01-09 (2014).

Pakravan, S., A. Hajimoradloo and R. Ghorbani: Effect of dietary willow herb, Epilobium hirsutum extract on growth performance, body composition, haematological parameters and Aeromonas hydrophila challenge on common carp, Cyprinu scarpio. Aquacul. Res., 43, 861-869 (2012).

Radhakrishnan, S., P.S. Bhavan, C. Seenivasan, R. Shanthi and R. Poongodi: Influence of medicinal herbs (Alteranthera sessilis, Eclipta alba and Cissus quadrangularis) on growth and biochemical parameters of the freshwater prawn Macrobrachium rosenbergii. Aquacul. Int., 22, 551-572 (2014).

Radhakrishnan, S., P.S. Bhavan, C. Seenivasan, T. Muralisankar and R. Shanthi: Effects of native medicinal herbs (Alternanthera sessilis, Eclipta alba and Cissus quadrangularis) on growth performance, digestive enzymes and biochemical constituents of the monsoon river prawn Macrobrachium malcolmsonii. Aquacult. Nutr., 21, 496-506 (2015).

Serra, D., L.M. Almeida and T.C. Dinis: Dietary polyphenols: A novel strategy to modulate microbiota-gut-brain axis. Trends Food Sci. Technol., 78, 224-233 (2018).

Sharma, A. and V. Sharma: A brief review of medicinal properties of Asparagus racemosus (Shatawari). Int. J. Pure Appl. Biosci., 1, 48$52(2013)$.

Sivaram, V., M.M. Babu, G. Immanuel, S. Murugadass, T. Citarasu and M.P. Marian: Growth and immune response of juvenile greasy groupers (Epinephelus tauvina) fed with herbal antibacterial active principle supplemented diets against Vibrio harveyi infections. Aquaculture, 237, 9-20 (2004).

Thakur, M., N.S. Chauhan, S. Bhargava and V.K. Dixit: A comparative study on aphrodisiac activity of some ayurvedic herbs in male albino rats. Arch. Sex. Behave., 38, 1009-1015 (2009).

Turan, F., M. Gurlek and D. Yaglioglu: Dietary red clover (Trifolium pratense) on growth performance of common carp (Cyprinus carpio). J. Anim. Vet. Adv., 6, 1429-1433 (2007).

Velmurugan, S. and T. Citarasu: Effect of herbal antibacterial extracts on the gut floral changes in Indian white shrimp Fenneropenaeus indicus. Rom. Biote. Lett.,15, 5710 (2010).

Waite, R., M. Beveridge, R. Brummett, S. Castine, N. Chaiyawannakarn, S. Kaushik, R. Mungkung, S. Nawapakpilai and M. Phillips: Improving productivity and environmental performance of aquaculture. World Fish, Washington, DC: World Resources Institute (2014)

Yousefi, M., S.M. Hoseini, Y.A. Vatnikov, E.V. Kulikov and S.G. Drukovsky: Rosemary leaf powder improved growth performance, immune and antioxidant parameters, and crowding stress responses in common carp (Cyprinus carpio) fingerlings. Aquaculture, 505, 473-480 (2019). 